УДК $179.7+614.253$

DOI https://doi.org/10.32837/apfs.v0i27.933

О. М. Шевченко

ORCID ID: https://orcid.org/0000-0002-1917-9472 кандидат психологічних наук, доцент, доцент кафедри суспільних наук Поліського національного університету

В. В. Мельничук ORCID ID: https://orcid.org/0000-0003-1569-3201 кандидат філософських наук, доиент кафедри суспільних наук Поліського національного університету

\title{
СОЦІАЛЬНО-ФІЛОСОФСЬКІ АСПЕКТИ ЕВТАНАЗІЇ В УКРАЇНІ
}

Постановка проблеми. Ідея евтаназії зародилася досить давно. Традиційна лікарська етика, ще з часів Гіппократа, містить таку заборону: «Я нікому, хто навіть просить про це, не дам ліки, які спричиняють смерть, а також не пораджу це робити» [3]. Світ змінюється, погляди людей на різні речі також. Не оминуло це явище евтаназію.

Цей термін запровадив англійський філософ Френсіс Бекон (1561-1626 роки) для позначення легкої безболісної смерті. Він складається з двох грецьких слів: “еu” - «добре», "thanatos" "смерть», тобто спокійна і легка смерть без мук і страждань. Нині евтаназію розуміють як дію, спрямовану на те, щоб припинити життя особистості, йдучи назустріч іï власному бажанню, i це має бути виконане незацікавленою особою. У суспільстві існують аргументи як за, так і проти евтаназії.

Під час дослідження цього питання ми використовували системно-структурний підхід. Він дає можливість забезпечити інтеграцію та впорядкованість наукових знань, а також конкретизувати і проаналізувати явище евтаназії через такі галузі людського буття, як медицина, право, морально-етична, релігійна, особистісна. Також за допомогою історичного методу продемонструємо, як це явище формувалося протягом століть у різних історичних епохах.

Аналіз останніх досліджень i публікацій. Аналіз наукової літератури, яка стосується цієї тематики, свідчить про значну кількість праць, присвячених питанню евтаназії. Проте це явище продовжує бути дискусійним серед фахівців різних напрямів (медицина, етика, право, філософія, соціологія, релігія). Значний науковий внесок у вивчення цього питання здійснили такі науковці, як С. Бородін, І. Бойко, Б. Волков, Н. Герасимчук, А. Гусейнов, Й. Дробик, О. Ковальова, Т. Кондрашова, Ю. Конюшкіна, Н. Сафаргаліна-Корнілова, І. Силуянова, В. Тарасюк, П. Тіщенко, С. Тихонова, С. Четав.
Метою статті є ґрунтовний аналіз та дослідження поняття «евтаназії», іï видів, досвіду зарубіжних країн, які легалізували евтаназію, а також грунтовне опрацьовування цього поняття у сучасному соціальному дискурсі та філософському науковому пізнанні і перспектив легалізації евтаназії в Україні.

Виклад основного матеріалу. В античну епоху траплялися випадки вбивства неповносправних дітей 3 євгенічних мотивів, а хворих і старців з економічних. Тепер евтаназія набуває масштабів загальновизнаної практики зі зростанням кількості тих, хто схвалює евтаназію, та визнанням за особою права вирішувати можливості щодо власної смерті.

У стародавній Індії, за півтора тисячоліття до Христа, засуджувалося втручання лікаря у процес відходу людини. Присяга Гіппократа є взірцем моделі, орієнтованої на моральну відповідальність за свої дії та пошани до життя людини. Вона заперечує будь-які евтаназійні дії та свідому співучасть лікаря у смерті людині [4]. Етика Гіпократа мала великий вплив на формування моральної свідомості медиків Стародавньої Греції і Риму. Настанови «Присяги» утвердилися в медичній етиці християнського світу, єврейської культури та медицини, мусульманської філософії медицини та наголошували на основному обов'язку лікаря - не зашкодити.

В античній Спарті здійснювалися евтаназійні чи євгенічні дії щодо хворих дітей та не здатних до боротьби людей похилого віку. Таку практику схвалив Платон у трактаті «Держава». Філософ стверджував, що лікар повинен дозволити померти особам, які не сприяють розвитку держави й самі не розвиваються [7].

Філософи-стоїки керувалися ідеалом атараксії (повного спокою і байдужості). Вони акцентували увагу на індивідуумі та його свободі і погоджувалися на відбирання свого життя та лікарську допомогу під час самогубства, коли хвороба чи інші 
обставини ведуть до розпаду особистості та обмеження власної свободи. Прихильниками евтаназії хворих дітей були Цицерон і Сенека. Останній зазначав, що це не гнів, а продуманий розрахунок. Процедуру «смерті за бажанням» чи умертвіння неповносправних в античності не називали евтаназією. Це поняття побутувало як філософський ідеал смерті, вільної від негативного досвіду.

Християнство істотно змінило свідомість, вбачаючи у житті Божий дар, а в самому стражданні - зміст і цінність, заперечуючи евтаназійну практику. Воно мало цілком новий погляд на вмирання, підкреслюючи гідність людини як Божого творіння, «образу й подоби» Бога, істоти розумної, вільної, обдарованої безсмертною душею. Церква відлучала від церкви за вбивство дітей. Навчання Церкви нагадувало, що агонія і вмирання людини $€$ участю в Страстях Христа та його наслідуванням. Філософ Тома Аквінський (1225-1274 роки) вважав, що «лише єдиний Бог має право визначати час життя і смерті» [1].

$\mathrm{y}$ ренесансових утопічних поглядах удруге 3'явилося звертання до теми евтаназії. Томас Мор (1478-1535 роки) в «Утопії» пропагує життя, яке має бути приємним та без страждань. Він стверджував, що вищі урядовці мають загітувати невиліковно нещасних до рішення померти, переконати їх у тому, що продовження життя для них є тягарем, а вони є тягарем для інших [5].

Від XVII ст. термін «евтаназія» починає означати «легку», «добру смерть». Англійський філософ Френсіс Бекон (1561-1626 роки) у праці «Про гідність і розвиток науки» зауважив, що професійним обов'язком лікарів щодо невиліковно хворих є евтаназія, котру потрібно розуміти як полегшення мук помирання. Представник позитивістській філософії Огюст Конт (1798-1857 роки) вважав, що заподіяння смерті хворому, який мучиться, можна трактувати як служіння для добра людства, що вище, ніж добро індивідуума.

Цікавою є думка Георга Вільгельма Гегеля (1770-1831 роки) про те, що через смертьіндивідуум найдосконаліше реалізує власну свободу. Людина є абсолютним господарем свого життя і смерті, проте не всі мають відвагу використовувати вроджену владу: слабкі особи потребують, щоб за них вирішували сильніші [2]. Фрідріх Ніцше (1844-1900 роки) переконував, що природна смерть не має сенсу. Людина повинна сама приймати рішення щодо фіналу свого життя. Ф. Ніцше стверджував, що пацієнтів із хронічними захворюваннями треба заохочувати до самогубства [6]. Погляди Г.В. Геґеля і Ф. Ніцше сприяли формуванню проевтаназійної ментальності європейців, і на зламі XIX і XX ст. пролунали гасла з потягами до евтаназії. А. Йост у творі «Право на власну смерть» (1895 рік) зазначив, що людське життя може набути «негативної вартості», що дає змогу його перервати.
На початку XX ст. формується сучасне поняття евтаназії як дії, що спричиняє легку смерть та прямує до її легалізації. У Німеччині (1930-ті роки) масово втілювалися пропозиції щодо евтаназії немовлят і дітей із вродженим каліцтвом та вадами розвитку, а також дорослих німецьких громадян, що є невиліковно чи розумово хворими. На початку 1940-х років А. Гітлер видав наказ про евтаназійну діяльність 3 дозволом на «смерть із милосердя" невиліковно хворим в останній стадії їхнього життя. Німецьке католицьке і протестантське духовенство, більшість медичного персоналу висловили протест щодо такого трактування смерті. Вони наголошували на тому, що жодна влада не має права вбивати людей, тим більше, неповносправних фізично й психічно. Злочини Другої Світової війни були шоком для суспільства, й народи вимагали виразного окреслення прав людини, її гідності, особистої свободи, права на охорону здоров’ я. Отже, виникла ЖАеневська декларація (1948 рік). Громадськість почала категорично відхиляти евтаназію. Страхіття війни спричинили в німецькомовному середовищі табу на термін «евтаназія». Однак через 20-30 років ситуація почала змінюватися. Питання евтаназії знову опинилося в центрі уваги з розвитком нових медичних технологій, з утвердженням права пацієнта на автономний вибір, появою громадських рухів, що відстоюють «право на достойну смерть» [10].

У 1980 році було засноване «Німецьке Товариство гідної смерті людини», що відстоює право допомагати померти невиліковно хворим, які можуть приймати рішення про момент своєї смерті. З 1982 року в Нідерландах була заснована Комісія з питань евтаназії для майбутньої легалізації евтаназї та асистованого самогубства. У 2001 році Вища палата парламенту Нідерландів затвердила «Контроль над закінченням життя за бажанням і допомогою в самогубстві, а також зміни до кримінального кодексу і закону про поховання i кремацію». Йдеться про те, щоби процедура «лагідної смерті» була відкритою та зрозумілою. Критерії лікарської практики, що містяться в законі, мають оберегти хворого від можливих зловживань медиків. Таким чином, евтаназія отримала суспільне схвалення. Тут постало таке спірне питання: «Практика повинна дотримуватися приписів закону чи закон має легалізувати те, що відбувається на практиці?» .

Подібні тенденції нині поширюються і в інших країнах. У Бельгії (2002 рік) парламент проголосив закон про легалізацію евтаназії і допомогу під час самогубства з критеріями, подібними до нідерландських. У Британії двічі (1990 року і 2015 року) відхилений закон про евтаназію, проте дискусія триває. Діяльність за легалізацію евтаназії у США має довгу історію. Сьогодні вона легалізована у п’яти штатах. 
32009 року евтаназія, як активна, так і пасивна, стала дозволена у Люксембурзі. У 2015 році до країн, які легалізували право на смерть, приєдналась Німеччина. Там дозволена виключно пасивна евтаназія, активна досі залишається забороненою й тягне за собою кримінальну відповідальність.

Світова історія свідчить про те, що до евтаназіі вдавалися лідери країн, у яких евтаназія визнавалася злочином, отже, для пересічного громадянина такий дар був недосяжним. Доволі схвальною була евтаназія 37-го президента США Річарда Ніксона, який після інсульту звернувся до лікарів з проханням не вживати неприродних заходів для підтримання його життєдіяльності у разі повторення крововиливу в мозок, коли він не зможе виявити свою волю. Щодо лікарів, які виконали волю Р. Ніксона, не було застосовано санкцій, але стосовно пересічних громадян лікарі не ставили би під загрозу свою кар'єру.

Так само свідомо припинив приймати ліки після консультації з особистим лікарем і складення заповіту президент Франції Ф. Міттеран, який страждав на останній стадії раку. Преса назвала цей вчинок президента мужнім, адже Ф. Міттеран до останнього залишався господарем своєї долі.

Значний резонанс викликав випадок у Нідерландах $з$ колишнім сенатором від Партії праці Е. Бронсхермою, який вдався до евтаназії у похилому віці, хоча не страждав на жодну важку хворобу. Він просто втомився жити і прагнув прискорити смерть. У цьому йому допоміг особистий лікар.

У зв'язку з наведеними вище евтаназійними тенденціями розглянемо правовий статус евтаназії в Україні. Законодавство України про охорону здоров'я забороняє евтаназію. У третій частині статті 52 Закону України «Основи законодавства України про охорону здоров'я» зазначається таке: «медичним працівникам забороняється здійснення евтаназії, навмисного прискорення смерті або умертвіння невиліковно хворого задля припинення його страждань» [14]. Активні заходи щодо підтримання життя пацієнта припиняють лише тоді, коли його стан визначають як незворотну смерть. Послідовність припинення таких заходів, поняття та критерії смерті визначає Міністерство охорони здоров'я України. Така ж норма дотримана в Цивільному Кодексі України. Згідно 3 частиною 4 статті 281 , «забороняється задоволення прохання фізичної особи про припинення iï життя» [15]. Хоча термін «евтаназія» тут не вжито, проте з контексту зрозуміло, що не дозволяється пришвидшувати смерть на прохання людини. Варто пам'ятати, що правова база в Україні нині нечітка й розмита. Ще десять років тому на законодавчому рівні в Україні питання евтаназії не дискутувалося. Сьогодні ситуація змінилася. У 2015 році до Верховної Ради було подано Проєкт Закону України «Про забезпечення права лю- дини на гідне закінчення життя». Усе частіше в українському медійному просторі простежуються проевтаназійні тенденції. Немало пропозицій виходить із юридичних середовищ, які переважно не займають чіткої позиції щодо евтаназії, їхні висновки досить двозначні.

Акцентуємо увагу на тому, що окремі дослідники евтаназії в Україні вважають іï легалізацію можливістю підстав для численних зловживань, збільшення тиску на невиліковно хворих людей 3 боку родичів, які охочі нажитись майном, до того ж це може призвести до призупинення нових відкриттів у медицині та може бути негативно сприйняте суспільством.

Стаття 3 Конституції України закріплює положення, у якому зазначається, що недоторканість та безпека людини в Україні є вищою соціальною цінністю [11]. У чинному Кримінальному кодексі України (далі - КК України) відсутня стаття, що регулює дії лікаря, який проводить евтаназію. Нині вона прирівнюється до вбивства за відсутності пом'якшуючих та обтяжуючих обставин. У Кримінальному кодексі відсутня норма, яка передбачає кримінальну відповідальність за вбивство, вчинене $з$ прохання потерпілого (невиліковно хворого), 3 мотивів співчуття до нього або задля полегшення його страждання. Вчинення евтаназії кваліфікується за частиною 1 статті 115 КК України як простий склад вбивства. Санкція частини 1 статті 115 КК України за умисне протиправне заподіяння смерті іншій людині передбачає позбавлення волі на строк від 7 до 15 років, тому суд під час покарання особи, яка вчинила евтаназію над хворим, може керуватися тільки цією статтею. Природно, що залежно від обставин справи евтаназія може бути врахована як пом'якшуюча обставина, хоча серед переліку обставин, які пом'якшують покарання (частина 1 статті 66 КК України), евтаназія (вбивство з мотивів жалю) не зазначена.

Сьогодні в Україні найчастіше трапляються випадки пасивної евтаназії, коли смерть настає внаслідок бездіяльності, а також соціальної евтаназії - нового виду евтаназії, зміст якої полягає в тому, що рішення позбавити когось життя виходить із тих міркувань, що кошти, необхідні для лікування безнадійно хворих дорогими препаратами, зберігаються для лікування тих хворих, які після одужання зможуть повернутися до життя. Дії винної особи у випадках вчинення пасивної і соціальної евтаназії логічно кваліфікувати за частиною 2 статті 137, частиною 2 статті 139 , частиною 2 статті 140 КК України, причому в усіх трьох випадках настання смерті є кваліфікуючою ознакою. Проте в країнах, де вже відбулася криміналізація евтаназії, кримінально-правові норми містять привілейований склад злочину, бо вбивство на вимогу невиліковно хворого вважається вбивством за пом'якшуючих обставин [13]. 
Сьогодні людство нерідко відмовляється сприймати себе як «пасивний матеріал» у руках Бога чи Природи, дедалі більше схиляється до того, щоби бути власником і творцем власного життя і себе самого.

Дії, які оцінюються у традиційній моральній свідомості як вбивство чи самогубство, у новому технологічному просторі біології і медицини набувають іншого статусу, який визначається іншими морально-етичними принципами, сутністю яких $€$ гідне життя і гідна смерть.

Деякі експерти вважають, що нова реальність значною мірою сприяє формуванню у медицини пліч-о-пліч із традиційною системою охорони здоров'я нової функції по забезпеченню смерті. Дослідження свідчать про те, що лікарі, які залучені до процедури евтаназії або асистованого лікарем самогубства, потім боляче переживають такий досвід.

Професійне обговорення евтаназії має забезпечуватися відповідним інформаційним супроводом для неупередженого i, головне, несенсаційного пояснення суспільству різних аспектів цього складного питання [12].

Висновки. Проблематика евтаназії, що розглядалася у статті, є досить актуальною. Деякі аспекти були лише засигналізовані, тому вони можуть бути вихідним пунктом для подальших досліджень. Зокрема, серед історичних питань докладніше варто представити думки сучасних філософів, які вплинули на нинішню евтаназійну ментальність. Необхідні подальші морально-етичні дослідження у біомедицині, формування суспільного зацікавлення щодо проблематики евтаназії. Від результатів поглибленого, міждисциплінарного обговорення цього питання буде залежати духовне обличчя світу XXI століття.

Варто зазначити, що проблема евтаназії $є$ актуальною лише для секуляризованої (вільної від релігійного впливу) свідомості. Позиція представників християнської релігії (католицизм, православ'я) є категоричною щодо можливості здійснення евтаназії, оскільки людина не владна над своїм життям, отже, не може самовільно визначати час своєї смерті.

Проблема евтаназії в етичному вимірі вкорінюється у проблеми життя та смерті, сенсу людського існування, ролі страждання у життя людини, призначення людини як такої. Ці проблеми належать до так званих вічних питань філософського знання, специфіка яких полягає у тому, що кожен цивілізаційний етап розвитку людства потребує власного варіанта їхнього вирішення.

\section{Jimepamypa}

1. Дробик Й. Евтаназія: історична ретроспектива та сучасний стан у світі й Україні. Наукові записки УКУ. Серія: Богослов'я. 2018. Вип. 5. Ч. 11. С. 143-165.

2. Иванюшкин А., Юдин Б. История медицинской этики и биомедицинских экспериментов на челове- ке и животных. Введение в биоэтику / ред. Б. Юдин. Москва, 1998. С. 103-104.

3. Платон. Держава / пер. з давньогр. Д. Коваль. Київ : Основи, 2000. С. 94.

$60 "$ Сенека Л. Философские трактаты / пер. 3 лат. Т. Бородай. Санкт-Петербург, 2000. С. 22.

5. Аквинский Фома. Сумма теологии / перекл. С. Еремеев. Киев, 2013. С. 209-210, 213-214.

6. Мор Т. Утопія / пер. з лат. Й. Кобів. Київ, 1988. C. 85.

7. Гегель Ґ.В. Феноменологія духу / пер. $з$ нім. П. Таращук. Київ, 2004. С. 309, 311.

8. Ніцше Ф. Генеалогія моралі / пер. 3 нім. А. Онишко. Львів, 2002. С. 285-286.

9. Юдин Б. Смерть и умирание. Эвтаназия. Введение в биоэтику. Москва, 1998. С. 287.

10. Сгречча Э., Тамбоне В. Биоэтика : учебник. Москва : ББИ, 2002. С. 366.

11.Конституція України : станом на 1 вересня 2016 року / Верховна Рада України. Харків : Право, $2016.82 \mathrm{c}$.

12. Про основи законодавства України про охорону здоров'я. URL: https://www.dec.gov.ua/ materials/zakon-ukra-ni-osnovi-zakonodavstva-ukra-nipro-ohoronu-zdorov-уa (дата звернення: 25.01.2021).

13. Цивільний кодекс України. URL: https://zakon4.rada.gov.ua/laws/show/435-15 (дата звернення: 25.01.2021).

14. Підстави для криміналізації евтаназії в Україні. URL: http://bo0k.net/index.php? $\mathrm{p}=$ achapter\&bid $=1205$ $0 \&$ chapter $=1$ (дата звернення: 25.01.2021).

15. Евтаназія: «хороша смерть», вбивство, акт милосердя чи право людини? URL: https://racurs.ua/ ua/2228-v-ukrayini-zagovoryly-pro-evtanaziu-horoshasmert-vbyvstvo-akt-myloserdya-chy-pravo-ludyny.html (дата звернення: 25.01.2021).

\section{Анотація}

Шевченко О. М., Мельничук В. В. Соціальнофілософські аспекти евтаназії в Україні. - Стаття.

У статті досліджено соціально-філософські аспекти евтаназії. Особлива увага приділена доцільності легалізації евтаназії в Україні. Автори обгрунтовують важливість і неоднозначність цього питання та звертають увагу на ризики щодо легалізації в Україні евтаназіі. Ця тема іноді є зовсім скандальною через нестачу правдивої інформації. Їй властиві страхи й домисли. Розбиратися в цьому питанні необхідно неупереджено, озброївшись досвідом інших країн.

Автори акцентують увагу на значущості кожного людського життя і звертають увагу на необхідність консолідації та співпраці окремих людей та інституцій із поширення правдивої інформації про евтаназію та виховання пошани до людського буття.

Більшість релігій не схвалює евтаназію. Католицька церква ставиться до неї вкрай негативно, розглядаючи помирання і смерть як важливу частину людського життєвого шляху. Вона вважає, що хорошу смерть треба заслужити своїми діяннями, а страждання наприкінці життя $є$ передумовою для кращого життя і блаженства в іншому світі.

Запровадження евтаназії нацистським режимом демонструє небезпеку поєднання етичних та економічних 
критеріїв, навіть прагматичних міркувань. Автори вважають, що в сучасному суспільстві обговорення питань евтаназії має виключати економічний аспект. Існує думка про те, що актуалізація евтаназії у західних суспільствах є зворотною стороною високої вартості сучасних медичних послуг. Тема вартості догляду за пацієнтом наприкінці життя не має бути табуйованою.

Ми розуміємо, що зараз в Україні не найкращий час для порушення цього питання. На жаль, сучасне сприйняття українським суспільством медичної сфери позбавлене довіри. Надзвичайне значення має питання довіри між лікарем та пацієнтом. Місія лікаря полягає у перебуванні на сторожі життя і поліпшення здоров'я громадян. Евтаназія здається йому зрадою професії і клятви Гіппократа. Дослідження свідчать про те, що лікарі, залучені до евтаназії або асистованого лікарем самогубства, важко переживають такий досвід.

Базовим завданням української влади у разі запровадження інституту евтаназії є його максимальне убезпечення від зловживань.

Ключові слова: суїцид, евтаназія, автоевтаназія, профілактика, етика, суспільство, держава, відповідальність, хвороба.

\section{Summary}

Shevchenko O. M., Melnychuk V. V. Socio-philosophical aspects of euthanasia in Ukraine. - Article.

The article examines the socio-philosophical aspects of euthanasia. Special attention is paid to the expediency of legalizing euthanasia in Ukraine. The authors justify the importance and ambiguity of this issue. They draw attention to the risks of legalizing euthanasia in Ukraine. This topic is sometimes scandalous due to the lack of truthful information. It is characterized by fears and conjectures. This issue should be dealt with impartially. It is worth considering the experience of other countries.

The authors focus on the significance of every human life. They call for maximum consolidation of institutions to disseminate truthful information about euthanasia. The authors welcome the education of respect for human existence.

Most religions do not approve of euthanasia. The Catholic Church treats it extremely negatively. It sees death and death as an important part of a person's life path. She believes that a good death should be earned by your actions. Suffering at the end of life is a prerequisite for a better life and bliss in another world.

The Nazi regime has demonstrated the danger of introducing euthanasia. He confirmed the threat of a combination of ethical and economic criteria and pragmatic considerations. When discussing euthanasia issues, you need to get rid of the economic aspect. The actualization of euthanasia in Western societies is the reverse side of the high cost of modern medical services. The cost of patient care should not be taboo.

In Ukraine, now is not the best time to raise this issue. Modern Ukrainian society does not trust the medical sphere. The issue of patient and doctor trust is very significant. Euthanasia is like betraying the profession and taking the Hippocratic Oath. Research shows that doctors involved in euthanasia or physician-assisted suicide have a hard time experiencing such an experience.

The basic task of the Ukrainian authorities in the event of the introduction of the institution of euthanasia is to protect it as much as possible from abuse.

Key words: suicide, euthanasia, autoeuthanasia, prevention, ethics, society, state, responsibility, disease. 